\title{
SPATIOTEMPORAL METAPHOR: VERTICAL AND HORIZONTAL AXIS OF TIME
}

\author{
Maria Tamarina Prawati \\ Universitas BundaMulia \\ mprawati@bundamulia.ac.id
}

\begin{abstract}
Linguistic relativity holds an idea that structure of language affects the ways people conceptualize the world. It grows into two hypotheses which are linguistic relativism and determinism. The hypotheses explain how language and culture relate one another. The close relation is reflected through different system of sign, systematic conventional use of sounds or written symbol in different society (Crystal, 1971 and 1992) as what occurs in metaphor. Metaphor is not only written symbol but also thought and action rooted in our bodily experience (Yu, 1998, p.43). Therefore time as abstract concept should be best conceptualized through space. Keywords: metaphor, spatiotemporal metaphor, ego-moving, time-moving
\end{abstract}

\begin{abstract}
ABSTRAK
Relativitas linguistik berlandaskan pada gagasan bahwa struktur kebahasaan mempengaruhi cara manusia dalam mengkonseptualisasikan dunia. Gagasan tersebut dihadirkan dalam dua hipotesis, yaitu relativisme dan determinisme. Kedua hipotesis ini menjelaskan bagaimana bahasa dan budaya berhubungan satu sama lain .Tercermin melalui hubungan erat yang telah sistem yang berbeda dicerminkan melalui sistem penandaan, konvensional sistematis menggunakan suara atau simbol tertulis dalam masyarakat yang berbeda (Crystal, 1971 dan 1992) sebagai suatu bentuk metaforis. Metafora tidak hanya semata suatu bentuk simbol tertulis tetapi juga tindakan yang mengakar dalam kehidupan dan pengalaman (Yu , 1998 , p.43 ).Oleh karena itu, waktu sebagai konsep abstrak haruslah dikonseptualisasikan melalui ruang.
\end{abstract}

Kata Kunci: metafora, metafora spasiotemporal, metafora ego-moving, metafora time-moving

\section{INTRODUCTION}

Linguistic relativity holds an idea that structure of language affects the ways people conceptualize the world. This hypothesis grows into two which are linguistic relativism and determinism. Based on linguistic relativism, language is considerably dependent upon the context of culture and reciprocally (Sapir, 1921; Beriln and Kay, 1969 as cited in Mahadi and Jafari, 2012). Meanwhile, language determinism highlights the idea that language and its structures limit and determine human knowledge, thought processes which means people with different languages have different thought processes. As the hypothesis explains how language and culture relate one another, the close relation is reflected through different system of sign, systematic conventional use of sounds, or written symbol in different society (Cyrstal, 1971 and 1992).

Metaphor, as part of language, is not only written symbol but it is also thought and action (Lakoff and Johnson, 1980, p.3). It is rooted in our bodily experience which relates to our body function and interaction with outer physical world where our knowledge is derived ( $\mathrm{Yu}, 1998, \mathrm{p} .43)$. Metaphor also becomes cultural model since it is popularly shared by the members of society and plays enormous role in their understanding of the world and their behavior in it (Quin and Holland, 1987, p.4). Specific example of metaphor as cultural model is temporal concept. Among two temporal concepts promoted by $\mathrm{Wu}$ (2009), time as space metaphor is the most prominent and investigated in numbers of researchers across culture. Through time as space metaphor, the abstractness of time can be well represented and pictured out through spatial experience. This temporal concept further mentioned as spatio-temporal which exists differently across cultures. Numbers of researches has put forward strong influence of culture towards the metaphor. Interested with how time is represented in spatial expression, this study would like to map out the spatiotemporal metaphor across cultures. This study attempts to highlights the dependent relationship between language and culture through spatio-temporal metaphor. 


\section{THEORETICAL REVIEW}

As we experience time, we can only move forward and will not be able to move backwards since we will never be able to go back to our past (Boroditsky, 2000). Since we can only move to one direction, what we experience will never be permanent. Simple yet clear example is our experience in going through seasons. Such as winter, it is not everlasting but begins and ends at certain time. Therefore in order to capture the sequential order of events, time is conceived as one dimensional linear model, two dimensional in cyclicity mode, and three dimensional helicity mode (Chen, 2014). In one dimension, time can only move forward from the past to the present toward the future. In cyclicity mode, time takes circular shape and moving forward from the past.

\section{Spatial Conception}

Hayward and Tar (1995) found that different language might represent space differently. Major spatio-linguistic distinction by Pederson et. al. is only between absolute and relative encoding of spatial directions and locations. Absolute spatial term refers to space reference which is independent from observer position. As an example Bandung is always south east of Jakarta when it is independent from observer position, thus south east is an absolute spatial term. As another case relative encoding of spatial direction is showed when an observer in Jakarta facing east, Bandung is on her right side.

For most of languages, relative spatial term is applicable mostly to describe layout in small array, while absolute spatial term is for larger spatial layouts. However, there are some languages make use of the spatial term differently. As an example is Tzeltal, a language spoken by Mayans in Chiapas, Mexico, on which some studies compare spatial frame of reference with English speakers. This different spatial conceptions showing how language determines the way we perceive the world. Brown and Levinson (1993) elaborated in the study that English speakers rely on egocentric frame of references by using left and right to refer on object. Such as in the sentence The bowl is on my right side. Geographical frame reference is also used in English merely to refer small array in an environment. The example of geographic frame reference is on a sentence such as Gabriel lives on the east of fifth avenue.

In the contrary Tzeltal speakers employ numbers of geographical frame reference to refer both objects near to the body (body defined coordinate system) and environment. They rather use east, west, north, and south as well as geological terrain such as downhill or uphill. For Tzeltal speakers, geographic frame reference is applicable for both small and large arrays.

\section{Understanding Time Through Space}

Lakoff (1990, 1993, and 1994) mentioned that time is best conceptualized through space. We can easily understand time which is abstract through experiencing space. In English, motion of an object is used to represent time such as:

- Time is flying by..

- Time has passed...

- It is getting closer to bedtime.

- Christmas is around the corner.

At another occasion, in English, time is passing in motion over a landscape such as:

- We are coming up on Christmas.

- We are getting close to Christmas.

The aforementioned illustration refers to two concepts of spatiotemporal metaphors which are ego-moving spatial metaphor and timemoving spatial metaphor. Ego-moving spatial metaphor is recognized as time landscape metaphor since the observer would finish walking the distance across the domain and go forward for the further future (Boroditsky, 2000). As an example, we often say that we have left the gloomy yesterday and walking toward the bright tomorrow. It means egomoving spatial metaphor perceive time as fixed space and limited by zone. For this concept, front is assigned to future or later event as in The revolution is before us. In this case revolution is later event happens in the future which is further along observer's direction of motion. Due to its fixed space and limited zone, time in ego-moving concept is considered as container. 


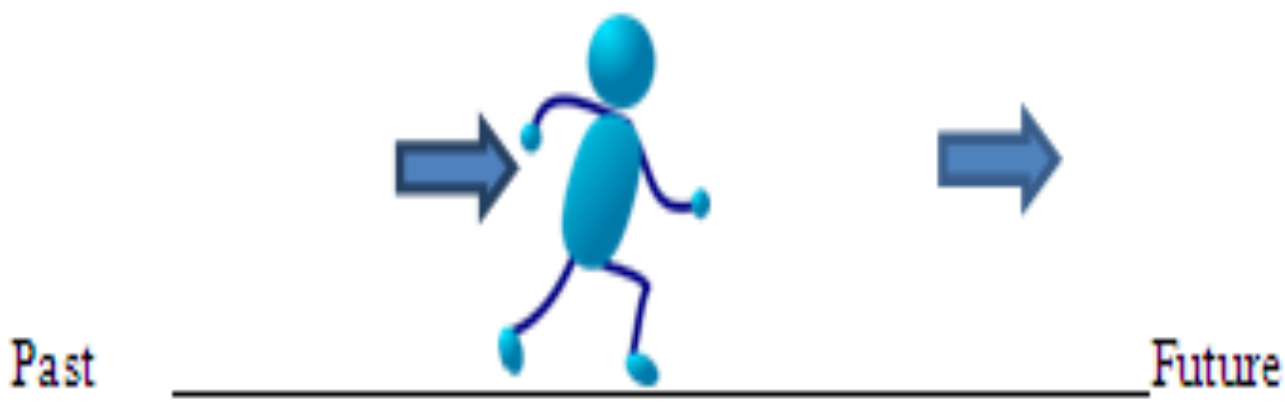

Figure 1. Ego-moving Spatial Metaphor

Unlike ego-moving spatial metaphor, time moving metaphor is fixed space and limited by zone, but move as a river or conveyor belt. In this concept, the ego is static, only observing time which is passing by. As an example the expression of
Thanksgiving is coming instead of We are coming toward Thanksgiving. This metaphor assign front is assigned as earlier event or past such as the revolution was over before breakfast. Revolution is referred as earlier event.

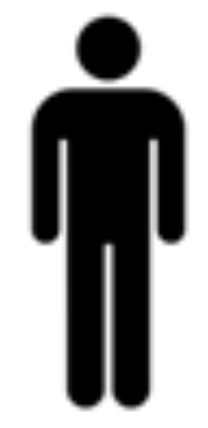

Past


\section{Future}

Figure 2. Time-moving Spatial Metaphor

Through the two concepts of spatiotemporal metaphors we can identify different way of placing ourselves as the ego on time orientation. In English, ego always takes a front to the future orientation. However not all languages takes a front to the future but front to the past orientation. $\mathrm{Li}$ (2005, p.40) mentioned that in Chinese ego has dual orientation which are front-to-thefuture orientation and a front-to-the-past orientation. For example, the best is waiting before you.
Another front-to-the-past orientation also exists in Aymara, an Amerindian language spoken in the Andean highlands of western Bolivia, southeastern Peru, and northern Chile. Metaphorically, their future is in back of ego, while their past appears in front of ego. Based on previous analysis by Miracle and Yapita (1981), the past is in front in Aymara because the past is known and the area in front of speaker is seen while the future is unseen. 
Further consideration regarding dual orientation of ego is differentiating futurity and posteriority. When we talk about front-tothe-past orientation will be different. With regard to the two aforementioned spatiotemporal metaphors, across languages people might represent time differently. There are different angle of how time is represented, such as employing one dimensional term which are in frontl at the back or ahead/behind, or even considering time axis as vertical (up/down) or horizontal (back/ ahead).

\section{DISCUSSION}

\section{Horizontal axis Spatiotemporal metaphor in English}

In English, horizontal line is dominantly used to represent time. Hausa () claimed that in English we can say left to right or right to left. The axis is represented in comic strip which flows consistently from left to right as well as the flow in book. Beside left to right practically people can also push the schedule back or move an appointment forward. As previously mentioned, people can also have opening meeting before closing meeting. There are also vertical metaphors used in English to talk about time, such as handing down heirloom or knowledge from one generation to another generation, the event is coming up. However, the use of vertical metaphor is not as systematic as in Mandarin (Chun, 1997a, 1997b; Scott, 1989 as cited in Boroditsky, 2001).

Beside the fact that there are horizontal and vertical axis, English spatial and temporal prepositions are differentiated into three which are zero-dimensional such as at (e.g. at this moment), two-dimensional on (e.g. on my birthday) and three-dimensional such as in (e.g in a second).

\section{Spatiotemporal metaphor in Aymara}

Both Mandarin and English verticalhorizontal spatiotemporal metaphors are well known and common among people. They represent future as either front or down. Expanding spatiotemporal metaphor study, a research found different pattern occurs among Aymara speakers. Aymara is an Amerindian language available in the Andean highlands of western Bolivia, southeastern Peru, and northern Chile. In this language, their past is nayra which refers to eye/front/sight while their future is qhipawhich is back/behind. Based on Miracle and Yapita's analysis (1981), the past is something that they know and can see, thus it is positioned in front of ego. In contrast, future is rather unseen or unknown, thus it is positioned behind ego. For them we can see our past but we cannot see the future.

As nayraand qhipaare applied, Nunez and Sweetser (2006) found that temporal uses of both are framed. On one hand, Nayra for Aymaran is also acknowledged as "first" as or "earlier than". Therefore similar to once upon a time or long time ago, Aymaran can start a story by using nayra. These examples indicate nayraas past which is Ego-Reference Point and also as earlier than which is TimeReference Point. On the other hand temporal uses of qhipa can refer to the future, or to relatively later times. It means that both are Ego-Reference points.

Indeed there is a catch of vertical spatiotemporal metaphors in Aymara such as alaylunisa(high Monday) which means next Monday that contrast the French use of "high" as something which has passed earlier.

\section{Vertical Axis \\ Spatiotemporal metaphor in Chinese}

To represent time, Mandarin speakers have both horizontal and vertical line which are represented as qiàn("front") and hòu ("back") as horizontal metaphors, and shàng("up") and xià("down") are vertical metaphors that are systematically used. Researcher notices that there are also different languages using vertical spatiotemporal metaphors, such as High Middle Ages in English or bas moyen age (low middle ages) in French, in which low refers to later time (Nunez, \&Sweetser, 2006). However in Mandarin, vertical spatiotemporal metaphors are more systematic and frequent.

Production of metaphor shàng( "up") and $x i a$ ("down") are related with the motion of sun. Chinese perceives sun rises from the horizon in the morning reaches the highest point at noon (Chen, 2014). Therefore the position of sun at noon which is higher than horizon is considerably later compared with afternoon, when the sun begins to set down. Unlike Mandarin, English might put the term 'up' as future and 'down' as the past. On other case, English might put the spatial 
position of 'up' as the past and 'down' as the future, similar with Mandarin. What is obvious in Mandarin, its spatiotemporal metaphors are static, which is proven in by the frequent use of time moving metaphors (e.g. The Christmas is coming up).

\section{Representations of time in relative spatial representations: Prompuraaw case}

Unlike English, Mandarin, or even other languages in the world, Prompuraaw, the remote Australian aboriginal community make use of absolute direction terms such as North, South, East, and West. When Boroditsky and Gaby (2010) asked the Prompuraaw people sets of pictures, they do not arrange it from left to right which is the correct temporal order of English speakers or from right to left as for Hebrew speakers. The people arrange it from east to west. Therefore when they are facing north, the card will be arranged from right to left. In the contrary when they are facing west, they will arrange the cards away from their body. Further arrangements will also be done depends on which direction they are facing.

The next experiment conducted was presenting dot to a Pormpuraawan and ask them a question such as, "If this dot is today, where is tomorrow?". As the result they arrange time from east to west. As the last experiment, the participants are requested to point in the four cardinal directions. They are considerably correct if they are within $60^{\circ}$ of the target direction. Every Pormpuraawan was correctly put them within $20^{\circ}$. Their way of thinking about time is totally different with Americans. Therefore even for those Americans who want to arrange the cards based on absolute coordinates, they will find it difficult due to limited knowledge on compass directions.

\section{CONCLUSION}

Language is an expression of how people perceive the world. On the other hand, language shapes people's thought which affect them in interacting with the world. Metaphor is closely related to our everyday life which is reflected in thought and action (Lakoff and Johnson, p.3). As it is bodily experience, metaphor is relate with body function and interaction with the outside physical world and from where our knowledge is derived (Yu, 1998, p.4).

Among temporal concepts, time as

space metaphors has been discussed meticulously and successfully mapped out across cultures. In spite of its abstractness it can be apparent and represented through experience. Representing time through space is significant by accessing spatial schema. Spatiotemporal metaphor is proven to be represented differently depends on how the society perceive the world. As time is represented in different dimension, some cultures might put the time as one to three dimensional. In three dimensional representation of time, it can move to three directions which are up-down, back-forth, and right-left.

In this study, English and Aymara are in horizontal time axis, which metaphors are represented through right-left and back-forth. English speakers mostly express their time through left-right and back-forth as in example that an opening meeting comesbefore closing meeting. Uncommon horizontal spatiotemporal metaphor is found in Aymara, in which nayra (eye/front/sight) is the past, while their future is at the back qhipa.

Vertical axis might occur in English and Aymara such as handing down heirloom and alaylunisa(high Monday), but doesn't exist as systematic and consistent as Mandarin used of shàng("up") and xià("down"). For Mandarin vertical axis, shàng("up") indicates past time, while xià ("down") indicates the future. However in spite of attaching spatiotemporal metaphor with rigid spatial representation, Prompuraaw spatiotemporal metaphor is attached with absolute direction terms such as North, South, East, and West. Therefore, Prompuraaw people sets of sequential pictures from East to West depending on compass directions. 


\section{BIBLIOGRAPHY}

Berlin, B., \& Kay, P. (1969). Basic color terms: Their university and evolution. California UP.

Boroditsky, L. (2000). Metaphoric structuring: Understanding time through spatial metaphors. Cognition, 75(1), 1-28.

Boroditsky, L. (2001). Does language shape thought?: Mandarin and English speakers' conceptions of time. Cognitive psychology, 43(1), 122.

Crystal, D. (1971). Prosodic and paralinguistic correlates of social categories. Social anthropology and language. London: Tavistock.

Chen, C. (2014). A Contrastive Study of Time as Space Metaphor in English and Chinese.Theory and Practice in Language Studies, 4(1), 129-136.

Sapir, E. (1921). An introduction to the study of speech. Language.

Gentner, D., Imai, M., \&Boroditsky, L. (2002).As time goes by: Evidence for two systems in processing space $\rightarrow$ time metaphors. Language and cognitive processes, 17(5), 537-565.

Holland, D., \& Quinn, N. (1987). Cultural models in language and thought. Cambridge University Press.

Imai, M., \&Gentner, D. (1997). A crosslinguistic study of early word meaning: Universal ontology and linguistic influence. Cognition, 62(2), 169-200.

Johnson, M., \&Lakoff, G. (2002). Why cognitive linguistics requires embodied realism. Cognitive linguistics, 13(3), 245-264.

Lakoff, G. (1993). The contemporary theory of metaphor.

Lakoff, G., \& Johnson, M. (2008). Metaphors we live by. University of Chicago press.

Mahadi, T. S. T., \&Jafari, S. M. (2012).Language and culture. International Journal of Humanities and Social Science, 2(17), 230-235.

Miracle, A., \&Yapita, J. D. D. (1981).Time and space in Aymara. The Aymara language in its social and cultural context, 33-56.
Núñez, R. E., \&Sweetser, E. (2006). With the future behind them: Convergent evidence from Aymara language and gesture in the crosslinguistic comparison of spatial construals of time. Cognitive science, 30(3), 401450.

Radden, G. (2004). The metaphor TIME AS SPACE across languages.na.

Whorf, B. L. (1952). Language, mind, and reality. ETC: A review of general semantics, 167-188.

Wu, Y. (2009). On the Relationship Between Metaphor and Cultural Models-with data from Chinese and English language. metaphorik. de, 17, 115134.

$\mathrm{Yu}, \mathrm{N}$. (1998). The contemporary theory of metaphor: A perspective from Chinese (Vol. 1). John Benjamins Publishing. 